\title{
Art as the Energy of Life Creative Process Representation of Sasak Womanhood in Visual Media
}

\author{
Lucky Wijayanti, ${ }^{\text {a Setiawan Sabana }}{ }^{\mathrm{b}}$ \\ aJakarta Institute of the Art, Address, Jakarta, Indonesia. email: luckyblueandwhite@yahoo.co.id \\ ${ }^{\mathrm{b}}$ Bandung Institute of Technology, Bandung, Indonesia.
}

\begin{abstract}
The idea of creation/formulation of the problem in the dissertation of art creation is the reality of women workers to the nature of femininity in performing arts as interpreted life energy into the problems of women workers. The idea is then formulated into the concept of creation, the role of women as the guardian of the family, gave birth to progeny, and the resilient nature of women as breadwinners for survival, even more importantly women as keepers of tradition. Through the creative process to create works of art by presenting a 'rasa' that can be captured and responded to by the brain into something that essence and recorded in the memory, (VS Ramachandran, 2012). The study was conducted using visual aesthetic and creative through the photographic process with the exploration of materials such as: objects generated tradition of Lombok, for example woven fabrics, woven and the other as an aesthetic element as well as elements of art such as: shape, line, color, shape, composition, and texture. As for all stages of the process based on the embodiment of the work of the working stages of the creative process by Csikszentmihalyi (1996), namely: preparation, incubation, insight / arcing ideas, evaluation, development, and presentation in the form of art exhibitions. In general it can be concluded, that in this aspect of the subject matter of the concept of women in the end that guarantees life for themselves women are women themselves. In the form of work, technical realization through the creative process with visualization methods.
\end{abstract}

Keywords: womanhood, rasa, the energy of life, creative process.

\section{INTRODUCTION}

Interaction author with the craftsman women often creates new ideas or bring new ideas in the works. Travel to various places that allow to interact with women workers, such as; vegetable traders in traditional markets, lifting stones, common bus conductor and so on in other areas, but it is also the batik artisans in Inderamayu, Cirebon, Pekalongan, Solo, Jogjayakarta; artisans weaving in Pekalongan, Lombok, Kupang, and; artisan pottery and woven in Lombok. Research in the village of Gunung Malang, Nyurbaya, Banyumulek, Lombok, West Nusa Tenggara, drawn to the women in the village are in daily activities weaving, plaiting, making pottery, dance, cooking, gardening, and planting rice, while the men reading the lontar, making residential buildings, making equipment, farming, gardening and so on. All of the women in the village of Gunung Malang activities gedhogan loom weaving is done in the front yard of their home. 
Women in Sasak community, has an important role in the organization of life. One example that reflects the major role is how the women weave cloth for children associated with local beliefs rituals performed until now. Starting when he was a baby by making umbak weaving, cloth to hold the baby when it is born later. By the time his son was a teenager, if men would undergo circumcision procession is required in Islam, then the mother will make woven fabric kerempen (circumcision ceremony) and kuris (hair cutting ceremony), a special fabric for the ceremony. The fabric color: red, yellow and black with stripes, size: width 10 to $20 \mathrm{~cm}$, a length of 1 to 1.5 meters. Furthermore, the fabric will be used by the child as a belt, to adult. When this child dies, the woven fabric will be cut and it is closed to the face. In addition to his mother, women who have entered menopause can be assigned weave fabric to complete the ritual. This woman is considered sacred. Before weaving must be provided andangandang, a kind of dish (offerings) penginang form, that is: betel, tobacco, gambir, yellow rice, yarns and fabrics. This dish is placed next to a loom, and must remain there for about two days weaving process. Thus the position of the mother or daughter plays an important role in the survival of the local traditional rituals.

Remarks at the top has two problems, the first position of women there who just became laborers or slaves to their master (employer), for example, women workers in the area of Pekalongan and secondly there are host to itself, for example, the weavers in village Gunung Malang, Lombok. Reality is author see that they work out the energy for survival with her family in art, apart from the issue of responsibility of men as the main breadwinner for the family. On the other hand that the woman should take the time portion as a breadwinner for the family. At first this activity is an activity to meet their daily needs, they do 'artistic activities' with the spirit or the spirit of art stored in the body. Activities done in simple houses with good awareness and earthy, even passed down through the generations.

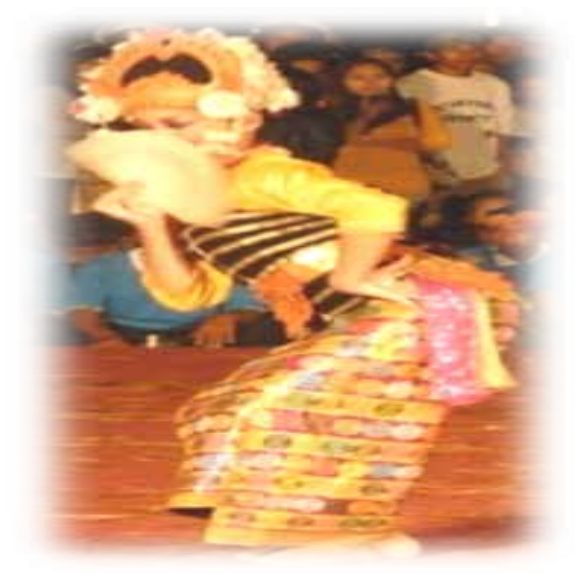

Dynamic movement of dancers gandrung Lombok

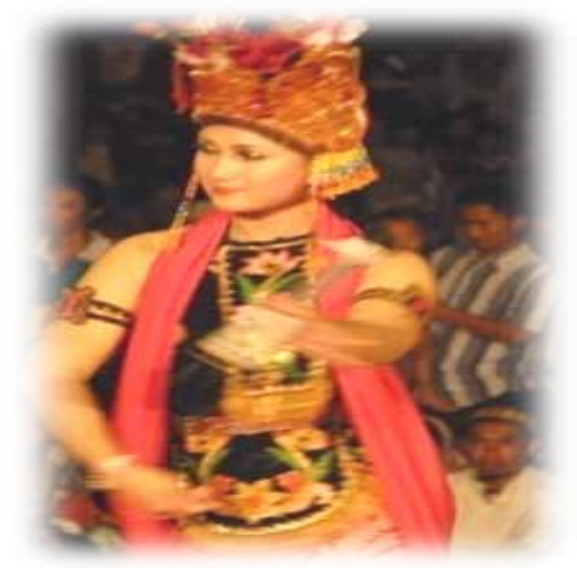

Dynamic movement of dancers gandrung Banyumas 


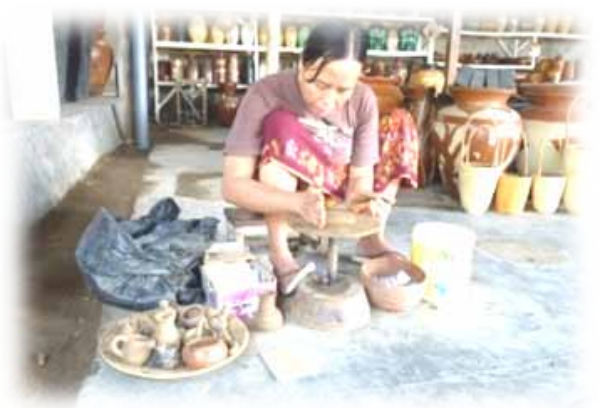

Women potters in the village Banyumulek.

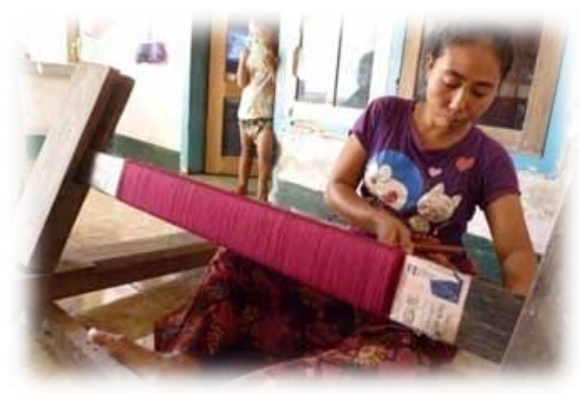

Women weavers in village Gunung Malang.

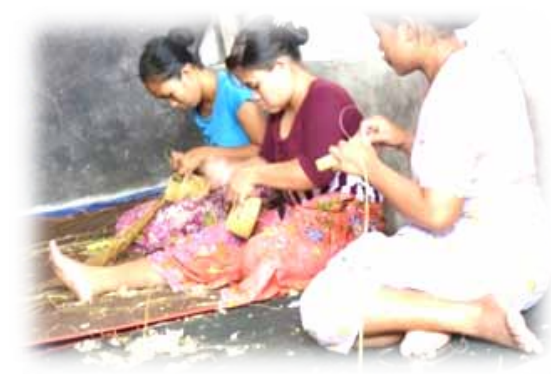

Women weavers in the village Nyurbaye.

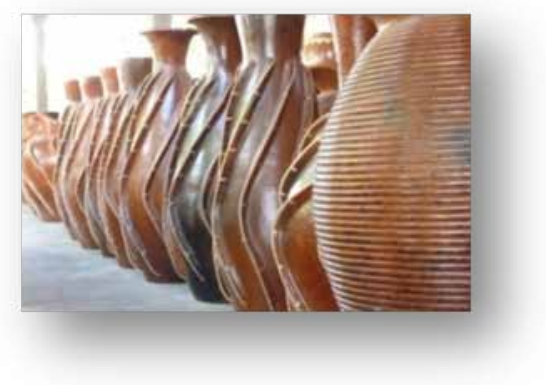

Pottery products with traditional burnt.

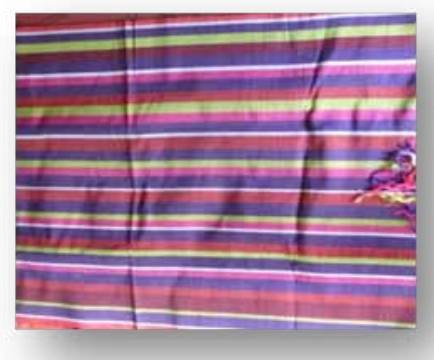

Weaving products with traditional loom.

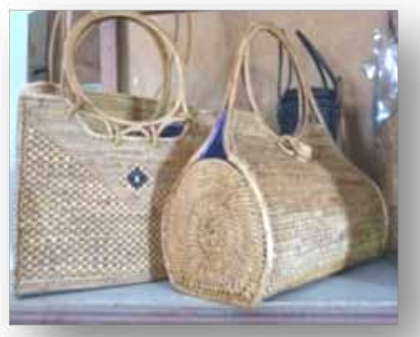

Bag products with ingredients ketak.

Table 1. Women workers: dancer Gandrung, making pottery, weaving and plaiting. Source: private documents. 2013.

\section{MATERIALS AND METHODS}

Based on the above background, there is an idea that can be formulated as follows:

a) How does the reality of working women with feminine characteristics in her life energy?

b) How to interpret the problems of women workers to build the concept of the creation of the art work?

c) How can a form of work that reflects the concept of female workers into works of contemporary art through the creative process on the exploration of form with visualization research methods?

Based on the authors' field observations, can be constructed a concept of creating works that are stated position of women which include: 
a) The role of women as guardians of childbearing families and their descendants, and the resilience of women as breadwinners for survival.

b) Making space for women's liberation as an artistic activity.

c) Realize the female figure through the aesthetic form as a representation of womanhood.

Thus the concept of the creation of the artwork shown in the following chart:

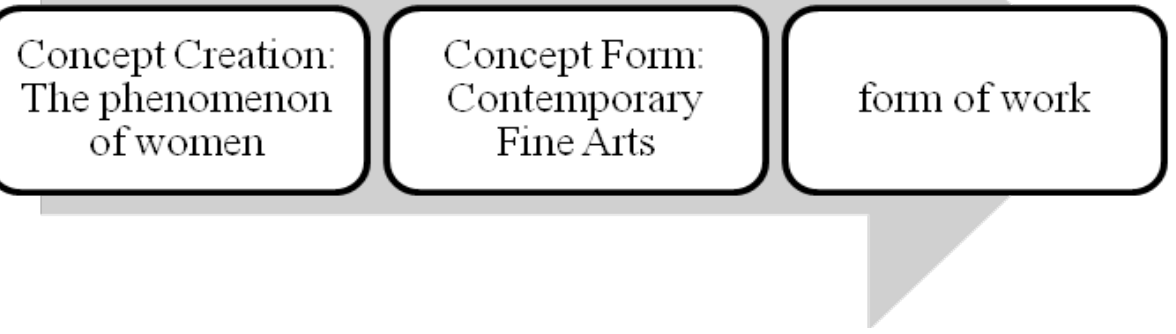

Chart 1. The concept of the creation of women's representation.

To realize the copyrighted works, an artist will do stage work by making flow or work procedures so that all activities undertaken will be recorded and well documented, it is very necessary if the work will be reproduced or further studied to develop, in the process of creating the work art, the author conducted several phases of work that refers to the stages of the creative process, as described by Mihaly (Csikszentmihalyi, 1996: 79), a psychologist, stated that the stages in the creative process, are: preparation, incubation, insight, evaluation and elaboration. To complete the stages of the process of creativity can be added 3 system components, that is: cultural order disciplines, experts in their field and the collaborators who helped in the process of work as an workers practitioner.

At the time of his creative activity, artists often follow feelings or condition to be comfortable in the work. When in the process of observation, suddenly automatically perform hand strokes that make up the figure, it is being implemented and allow it to get the best sense and produce some imaging. After that back again contemplate and make the first conclusions with reference to the concept of manipulating the material and estimation techniques to be used. This process continues to flow like a spiral starting from the exploration stage, the design stage to go to the embodiment.

Using the methods of visual/creative, visually that is thought to make the ideas that will be visible through a variety of techniques to explore issues of the projects studied so finding something or new findings in this study. This research-based practice and experiment by using visual skills to externalize and communicate concepts, interpretation, evaluation, and so on; so that this will happen in collaborative research as a means of sharing information, get feedback and generate new ideas, (Gray, Carole and Malins, Julian: 2004). Visual methods using the pictures are very necessary because in one picture can tell a thousand words and express some meaning, can 
imagine the use of materials / ingredients, creating an open discussion among viewers, get creative response, and allows the use of technology in realizing the image. Here's how to put the majority of research into the chart mind map:

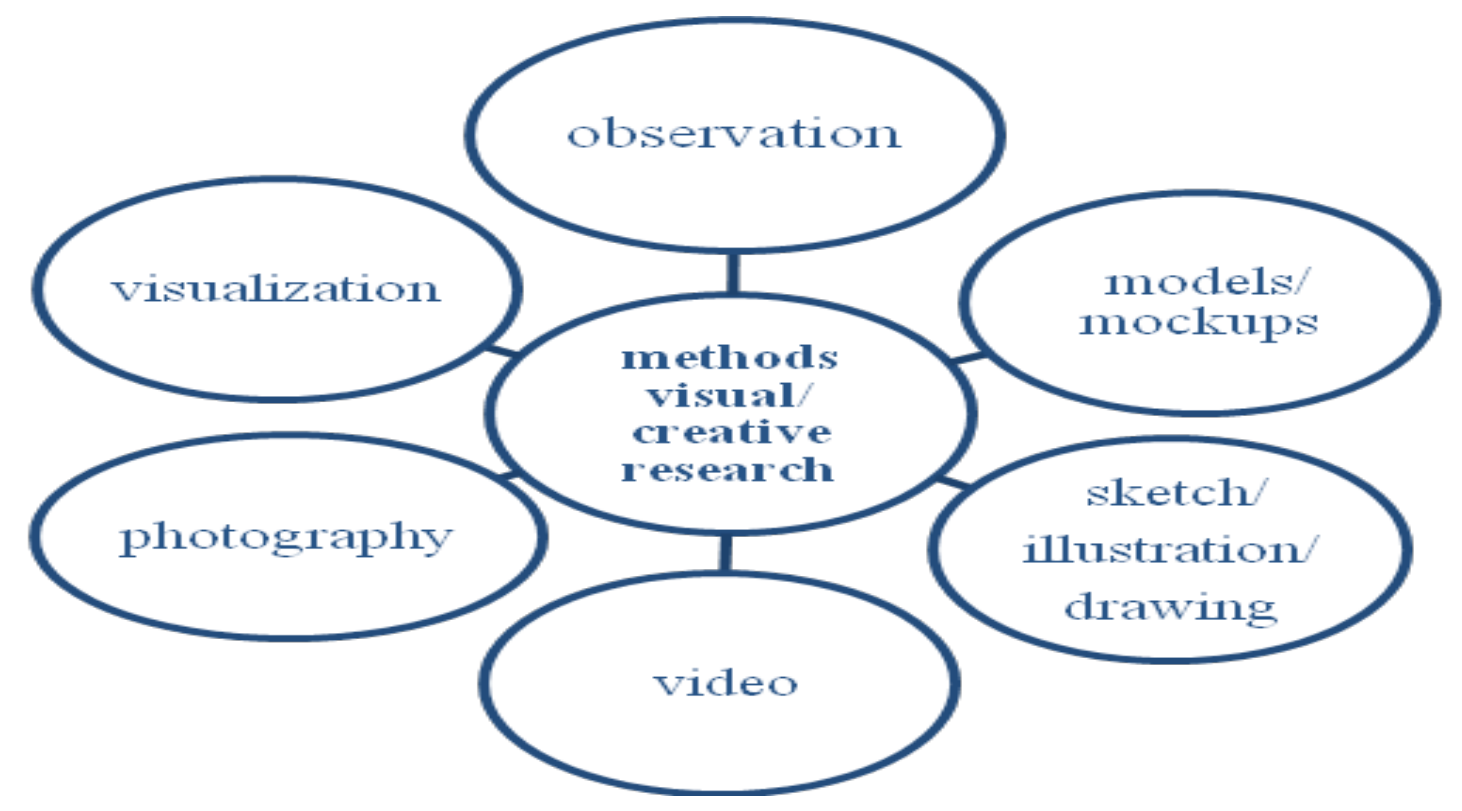

Chart 2. Part concept visual mind map method.

\section{DISCUSSION}

\section{a. Visual documentation:}
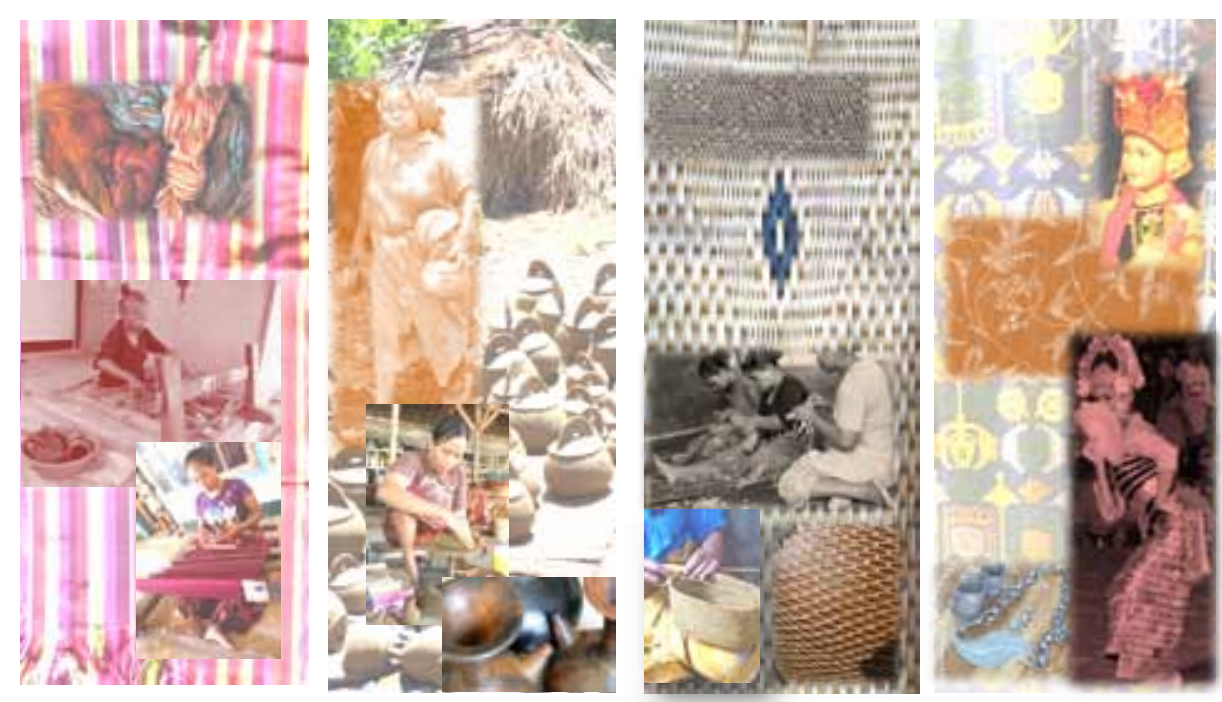

Figure1. Documentation photography. Source: private documents. 2013. 


\begin{tabular}{|c|c|c|c|}
\hline No & $\begin{array}{l}\text { Activity- } \\
\text { Location }\end{array}$ & Matter / object & Analysis \\
\hline 1 & $\begin{array}{l}\text { Weavers, } \\
\text { Village } \\
\text { Gunung } \\
\text { Malang }\end{array}$ & 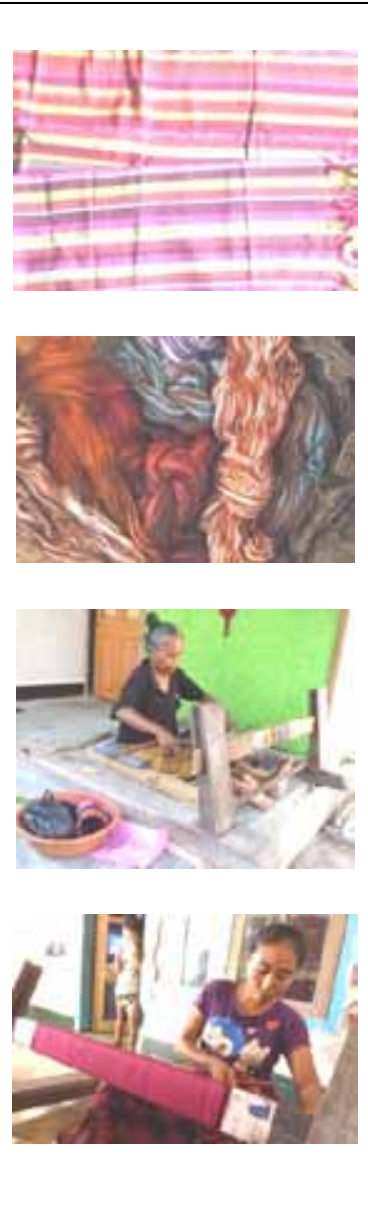 & $\begin{array}{l}\text { Woven fabric, } 200 \mathrm{~cm} \times 50 \mathrm{~cm} \\
\text { Used as a shawl for women at the party. } \\
\text { Synthetic colored cotton yarn, the basic } \\
\text { material for cloth weaving as warp and } \\
\text { feed. } \\
\text { A woman weaving with a loom gedhogan } \\
\text { on the front porch of the house. At the } \\
\text { time weaving in sitting posture, with } \\
\text { your back straight, arms and legs should } \\
\text { be strong and hold on as you pull the } \\
\text { loom, weaving is done with a regular } \\
\text { movement and discipline. } \\
\text { A woman was weaving while keeping } \\
\text { her child. They weave to meet the needs } \\
\text { for clothes. The resulting cloth should not } \\
\text { be sold, they gathered for ceremonial or } \\
\text { religious event. Work independently, } \\
\text { should not as a laborer. }\end{array}$ \\
\hline 2 & $\begin{array}{l}\text { Potters, } \\
\text { Village } \\
\text { Banyumulek }\end{array}$ & $=$ & $\begin{array}{l}\text { Banyumulek, located in the district of } \\
\text { Kediri (West Lombok), } \\
\text { At first they learn to make the barrel as a } \\
\text { water container, pot for rice and } \\
\text { wuwungan container, roof decoration in } \\
\text { the shape of animals horse. Until now still } \\
\text { be made. Very interesting of these is the } \\
\text { art of pottery in the combustion process } \\
\text { does not use the stove, but put } \\
\text { earthenwares ready burnt on firewood } \\
\text { stack and covered with straw and then } \\
\text { burned on the terrain, this is done by } \\
\text { fellow members of the family worked } \\
\text { together. }\end{array}$ \\
\hline
\end{tabular}




\begin{tabular}{|c|c|c|c|}
\hline 3 & $\begin{array}{l}\text { Plaiting ketak. } \\
\text { village } \\
\text { Nyurbaye }\end{array}$ & 60 & $\begin{array}{l}\text { In this Nyurbaye village almost all } \\
\text { women plaiting material proficient ketak } \\
\text { (a kind of plant that grows on the edge of } \\
\text { a cliff). They worked as laborers and } \\
\text { gathered in a a kind of a souvenir shop } \\
\text { that sells products made from ketak. They } \\
\text { work after finish cleaning the house until } \\
\text { late afternoon. } \\
\text { This job requires a high skill, because } \\
\text { many of the processes that must be done } \\
\text { to make a product: } \\
\text { - Preparing materials with plant stem } \\
\text { skinning ketak (Lygodium } \\
\text { Circinatun). } \\
\text { - plaiting such that the size of such } \\
\text { arrangement, forming short lines that } \\
\text { form a motif. } \\
\text { - 3-dimensional shape in the form of } \\
\text { containers, boxes, round, tube and } \\
\text { others. } \\
\text { - Clearly visible bright-dark, because } \\
\text { the texture of the blend material } \\
\text { which is owned clack natural colored } \\
\text { like brown and black. }\end{array}$ \\
\hline 4 & $\begin{array}{l}\text { Dancers } \\
\text { Gandrung } \\
\text { Lombok }\end{array}$ & & $\begin{array}{l}\text { Gandrung dance that evolved in Sasak } \\
\text { community on Lombok is a dance show } \\
\text { performed in the field, accompanied by a } \\
\text { set of gamelan musicians, poetry, } \\
\text { tembang (sabarungan, lelakaq, sandaran; } \\
\text { Sasak) and the audience, creating a circle. } \\
\text { The development time of this dance is } \\
\text { often shown as a symbol of expression } \\
\text { Sasak community on Lombok as a social } \\
\text { dance. } \\
\text { Dancer costumes either: a) gelung: } \\
\text { headdress made of frangipani flower, b) } \\
\text { gempolan: ear ornaments made of } \\
\text { frangipani flower, c) bapang: decorative } \\
\text { neck, d) stagen: cloth wrapped around the } \\
\text { chest to the waist, e) eleq-elaq: pectoral, f) } \\
\text { gonjer: colorful scarves, g) long cloth, h) } \\
\text { fan. }\end{array}$ \\
\hline
\end{tabular}




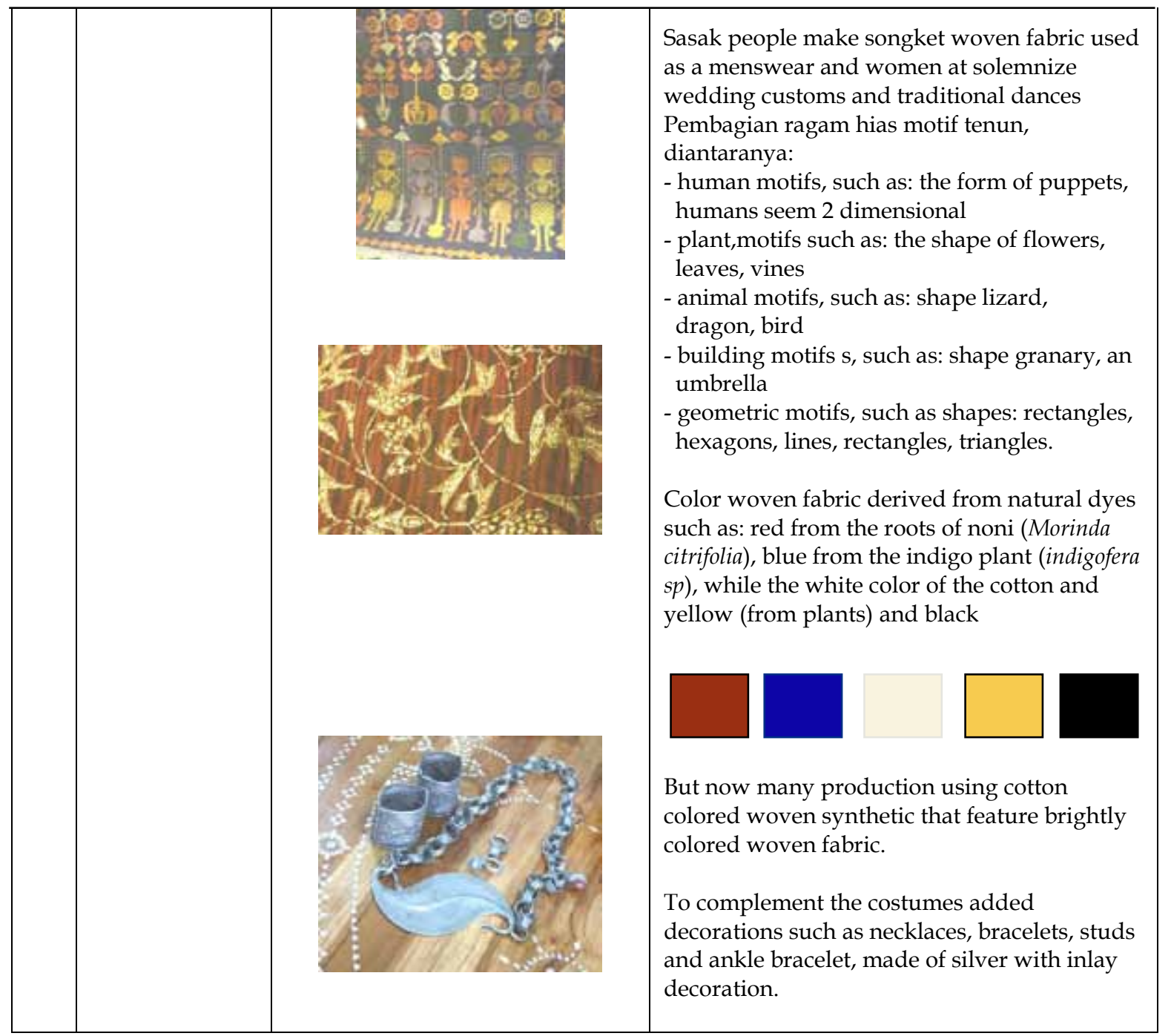

Table 2. visual documentation (Source: private documents, 2013)

\section{Subject matter :}

Research in Lombok the Sasak tribe society, the position of women plays a very important that as a ruler, for example, by known the term that is bumi nine, or motherland. Inen bale core that is part of the house as a place to proceed in the family are the property of women, who in Sasak inheritance system, all of the home and its contents will be passed on to the women. Whereas in the calculation of custom homes Sasak architecture, women's feet are used as a benchmark in the calculation of the size of the parts of the house. Gunung Malang (Lombok Barat), Bayan village (North Lombok), Pujut districts (Central Lombok), District Sembalun (East Lombok), sub Jonggat (Central Lombok) has the trust activities which are still performed and maintained in the form of cultural rituals associated with the groove human life from birth to death. Three parts of human life: birth, life and death. The third cycle is associated with weaving tradition, symbolized by the birth of woven fabric Umba ', the life of the fabric used for clothing or clothes, with a death shroud woven fabric 
and fabric Usap, cloth to cover the face when he died. This understanding is related to cosmology.

The cosmologists often reveals the meaning and qualitative relationships through the idea of the four pillars that are the substance of life origins of the universe, the four pillars represent the properties that it contains not only the physical state alone. Pillars are: a) land: dry and cold nature, b) water: wet and cold nature, c) air: wet and hot properties, d) fire: dry and hot properties. These four elements represent four qualitative stage which is the existence of the earth, from the lowest stage towards high levels, from the dense toward soft, from dark to light. Analogy with the existence of the woven fabric are: the land watered produce cotton plants with photosynthesis and air support these plants produce flowers of cotton, then cotton is spun, made yarn and woven into fabrics. This is the fabric used in the human life cycle.

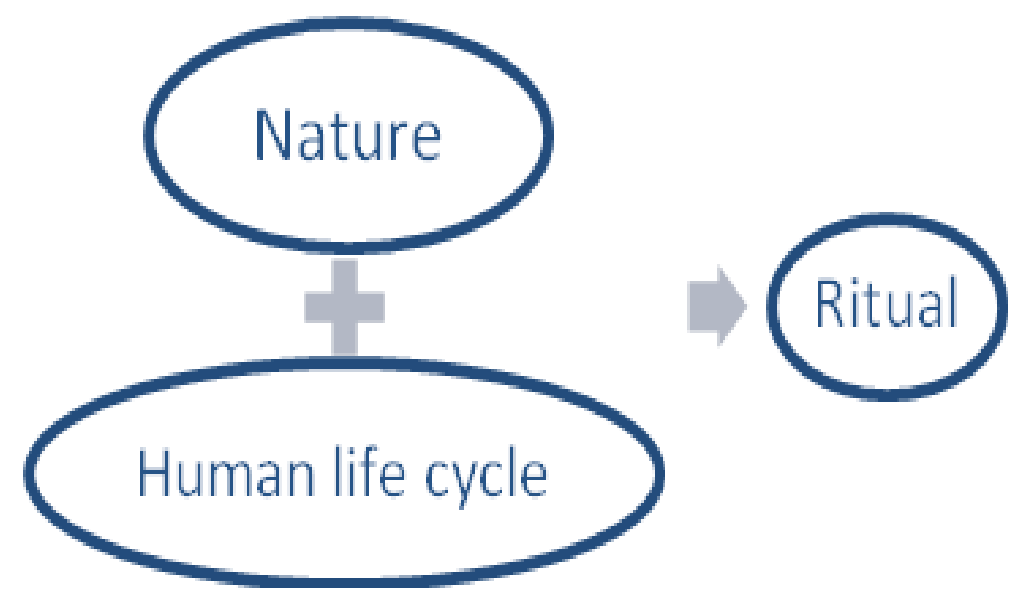

Chart 3. The relationship of man with nature cosmology.

In this ritual human beings trying to connect between the energy of nature and human life, the ritual is a symbol of love represented with woven fabric Umba 'which is used to hold the fabric and wrap (hug) newborns, this woven fabric as the link between life, natural and human, in order to remain united energy, thus the material of the fabric must be derived from nature, namely cotton.

Umbak fabric 'has a name such as fabric bajak sari motif, kombong motif and others there are 8 names. The motive of lines because it comes from weaving techniques. Weaving technique originating from North Bali (Gringsing) is what can weave the threads into a piece of cloth that will be used as cover material of the human body. Color motif consists of white symbol of bones meaning of life, the red symbol of the blood means life, yellow symbol of the body means power and black symbol of bones means death. This fabric is woven by a woman saint, that old woman who has been through a period of manapause. Fabric for this ritual is usually woven with the intention aimed at sender later in the ceremony beforehand, weaving activities carried out on Monday or Thursday, loom usually placed near the sort of offerings, weaving is done for one week. For one child usually takes one or two woven fabrics, even if it is able to achieve eight woven fabric according to the ability of their parents. 
Women who weave these fabrics usually are descendants of the elder and taught women how to weave in the interests of ritual. This woman has a companion called for help ontang antin. Later ontang anting women is what will replace them if dead. If you look at the illustration of the role of women who started from the the girls become teenage girl learning to weave, continued to marry and become a mother and have children, then become an old woman who later headed the sacred feminine. Can be stated that the dignity of women as carers and tradition successor.

Women as guardians of tradition, all the ceremonies led by women (inen gawe), the logistics worked out by female guards (inen menik), the holder of the cosmos or supervisory ritual performed by men. Indigenous culture can be kept alive because it is done with the activity of the ritual, the ritual still running because it is still useful and needed by community supporters, in carrying out the rituals required media is woven fabric made of cotton raw materials.

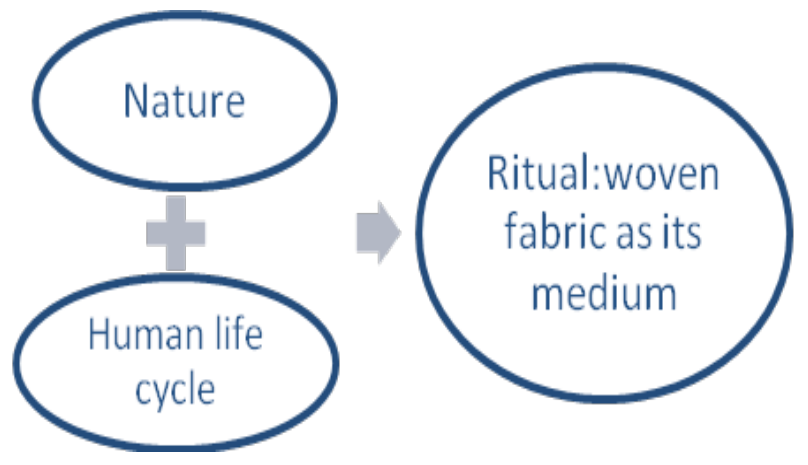

Chart 4. Role of woven fabric in rituals.

Sasak women should be able to weave before getting married and bringing food to the fields by means of upholding the goods on the head, this can be seen as a concept of balance. If there is no regeneration of the women who weave, then there is no fabric produced as its medium of ritual, then one day traditions will be lost. Women who make woven, because men do not deserve to work weaving. To keep the tradition maintained the required documentation and conservation as well as trying to be open to change while still maintaining traditional values in order to stay awake cosmological ideas. Ritual Umba fabric 'This is the original Sasak before Islam entered. Cosmological thinking associated with mountains, sea, land, water, fire, wind, which gave birth to the custom value so that there is a ritual activity. Traditional society in general does not know the culture, there is a value, people familiar with the tradition of the required value by way of ritual, this ritual gave birth to the technical aspects (weave), incantations (literature), cymbals (offerings), needed something that would give birth to the social system namely: the elite, the middle and the public. 


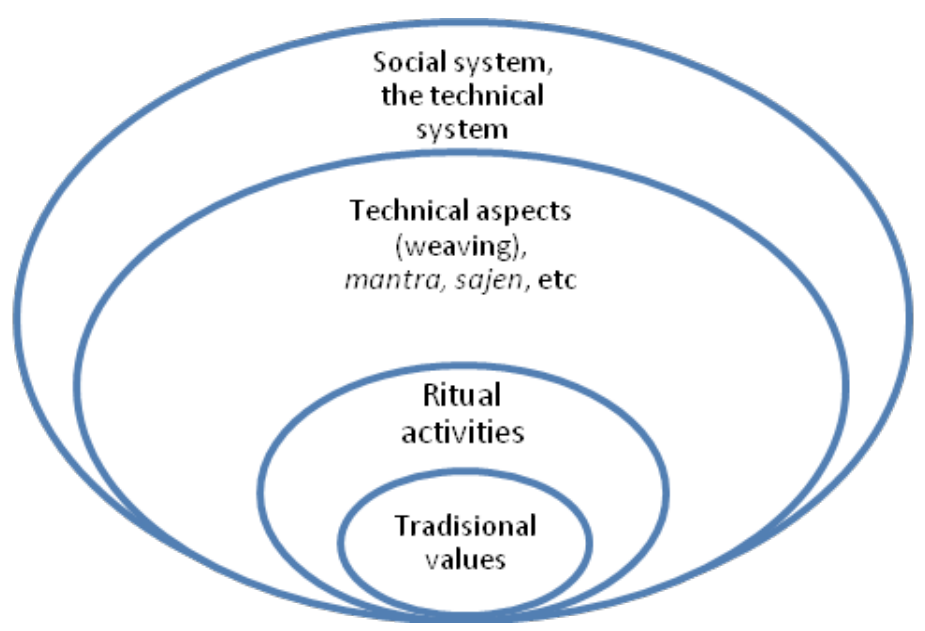

Chart 5. The social system

How high the role of women as guardians and keepers of tradition, that tradition remains on earth Sasak Lombok. The origin of this ritual about 200 years ago, is now a ritual with a Umba fabric 'this is rarely done, but it is still done by the Sasak people inland. Currently ritual tradition kuris (haircut), using Umba fabric 'was done and done at the time of the Prophet Muhammad's birthday event, because of the times, the ritual is dependent on the beliefs of each family.Now, in the village of Gunung Malang and Bayan village, the women still do the work of weaving is done at night or after returning from the fields, the woven fabric used for clothing or be traded to travelers, 'kemali' fabric only to be used only. Weavers in this village there are about 100 women weavers of 400 heads of household. Government (village head) to provide thread stalls, direct buyers to buy fabric to the weavers. Regeneration in this village is being done, for teenage girls after school they will soon weave.

The next how the link between the material obtained from the research is conducted in the field in the creative process by incorporating elements of 'rasa' and 'essence' is in the form of work. Through the relationship between how the brain works of art, like an artist Hindu in India see anatomical statue of the goddess with a large chest size, waist very slim with the hips that contains and solid, it depicts the artist makes it to 'sense' romantic love, sexual ecstasy, feminine, grace, and perfection of a fertility goddess. As the rasa and essence of it can evoke a certain mood to the observer, that is by 'capturing the very essence', and interpreted as something to 'evoke an emotional response directly' so that it can capture the real essence of art.

In addition, how an artist captures the essence on an object? so as to produce a work of art that has the effect of radical change (the peak shifteffect). How the principles of this radical change effects associated with the creative process, so that the object can be stand out and very quickly captured by the nervous system of the brain, namely through objects caricatured, exaggerated, amplified, in the highly right, so that the interaction between the nervous system of the brain with artwork. (Vilayanur S. Ramachandran: 2012). 


\section{b. The creative process:}

\section{b.1. Exploration of materials and techniques}

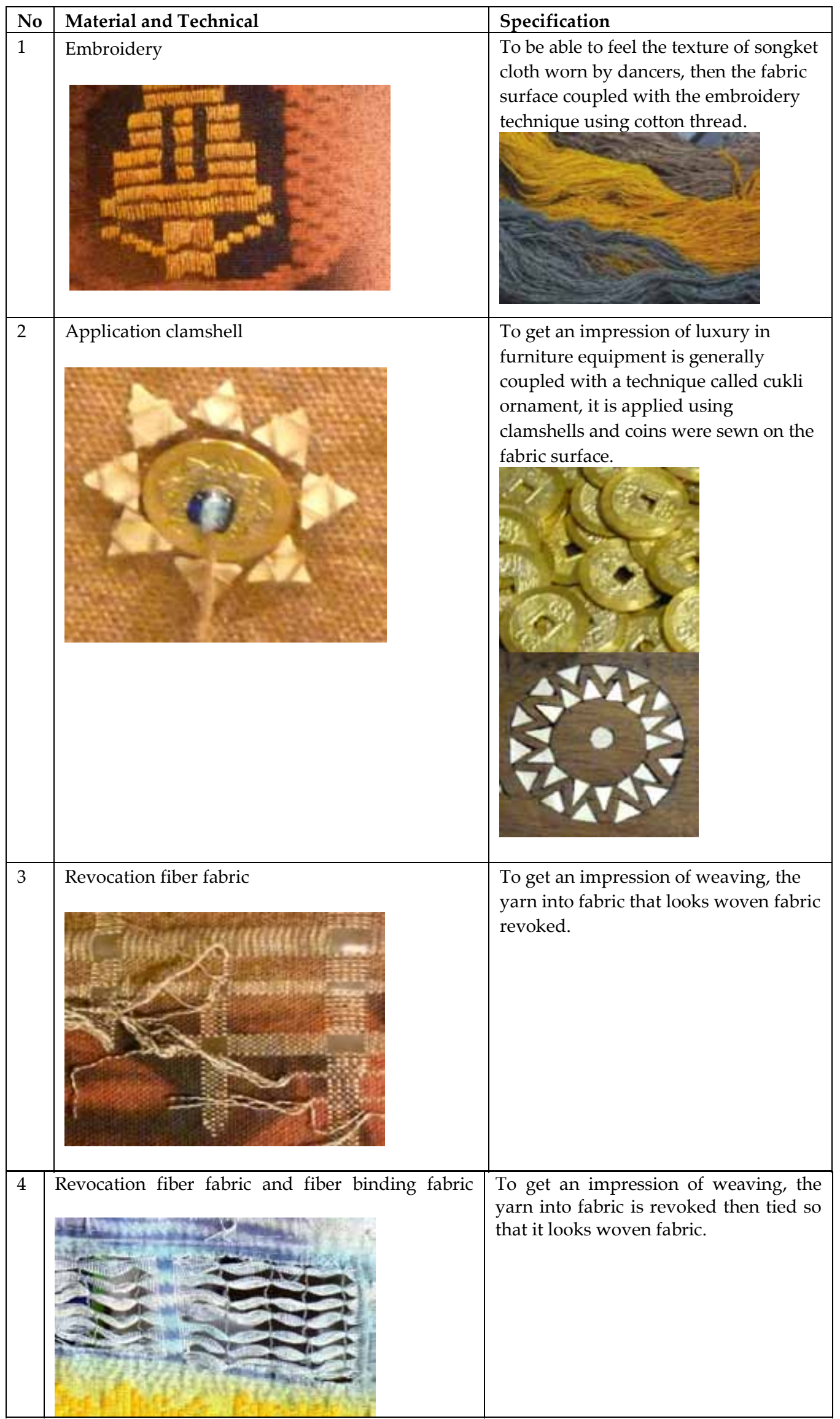




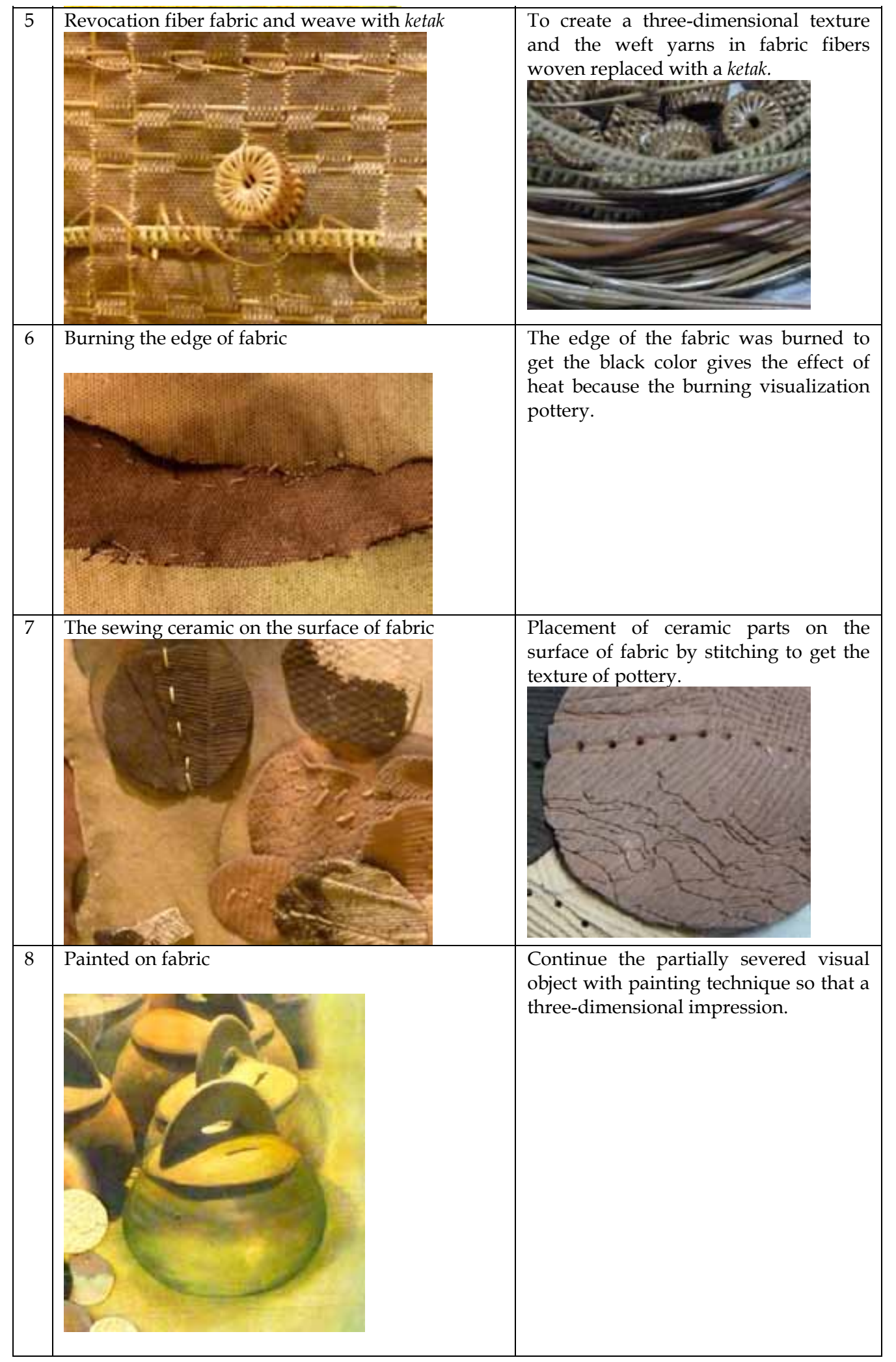

Table 3. Exploration of materials and techniques. 


\section{b.2. Visualization Techniques}

Works in the presentation is a photo documentation in different formats, because the techniques used are the above photo print fabric material, so it can be freely explored, such as sewn, embroidered, woven, burned, this is in accordance with the activities of Sasak women workers. The aim is to give experience to the visitors to feel the sensation as it allowed to touch the works in order to feel the various textures such as texture threads, clack and pottery.
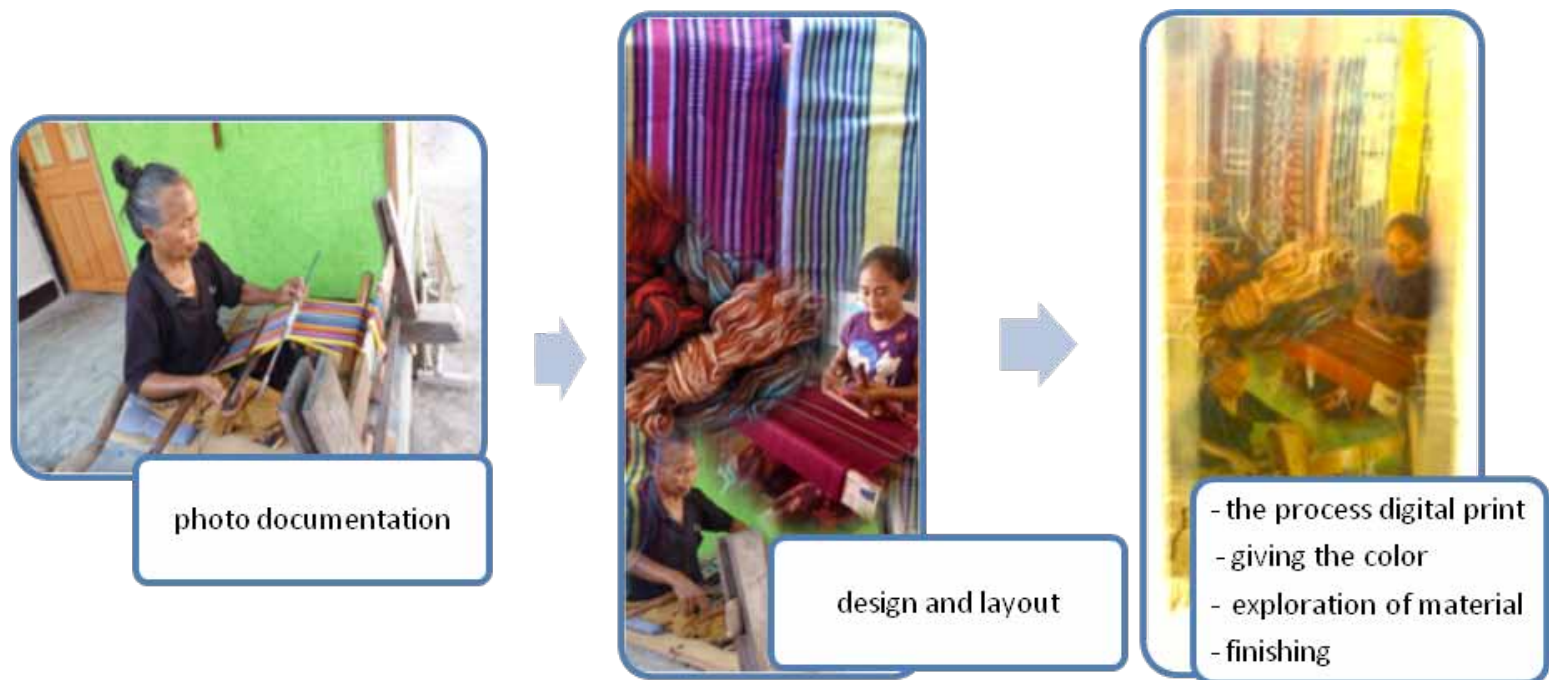

Chart 6. The process of visualization techniques.

\section{c. Presentation of Fine Arts Exhibition}

Exhibition of the work is a form of presentation that are new findings from the research in the creative process of Sasak women who told about the work and toughness of women workers. This opens up a dialogue between artists and art critics, artists, and the public to promote the appreciation of art and inputs in order to give a positive assessment of the creative process in the work.

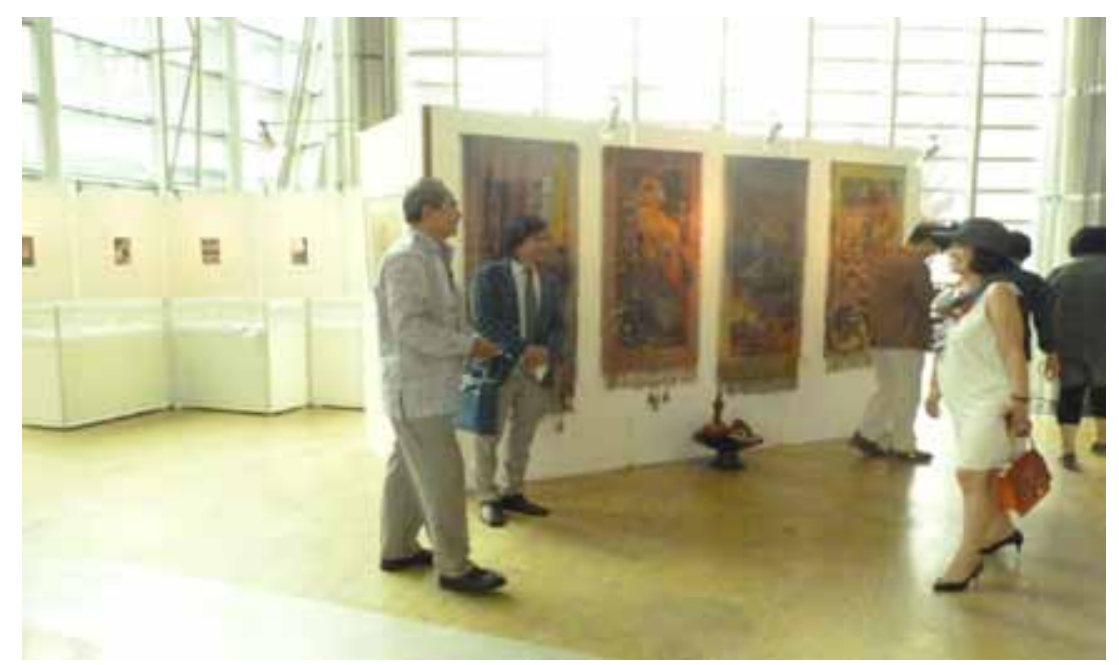

Figure 2. Visual Arts Exhibition at the "Beyond \# 2 Border in Art Indonesia and Korea, Lobby Theater Jakarta, Taman Ismail Marzuki- Jakarta, 25 - June 27, 2015. 


\section{CONCLUSION}

Based on the results of research in the field, the concept of thought Ramachandran, about extreme figure, then compiled estimation phase of work, that is:

1) Works of photographic documentation can be presented visually by showing a 'rasa' of womanhood Sasak through: a). Texture woven fabric, woven grass, and pottery, b). Lombok natural color, the color material, c) woven technique is applied to the surface of the fabric, d). Material support as aesthetic elements that characterized Lombok such as cotton yarn, kepeng coins, pottery, grass, clamshells, silver accessories.

2) Impression on women workers face photo becomes the emphasis because the visually can talk and tells about the world of work.

3) Remind to the public, that there are female workers in Lombok who do the work of art as the energy of life.

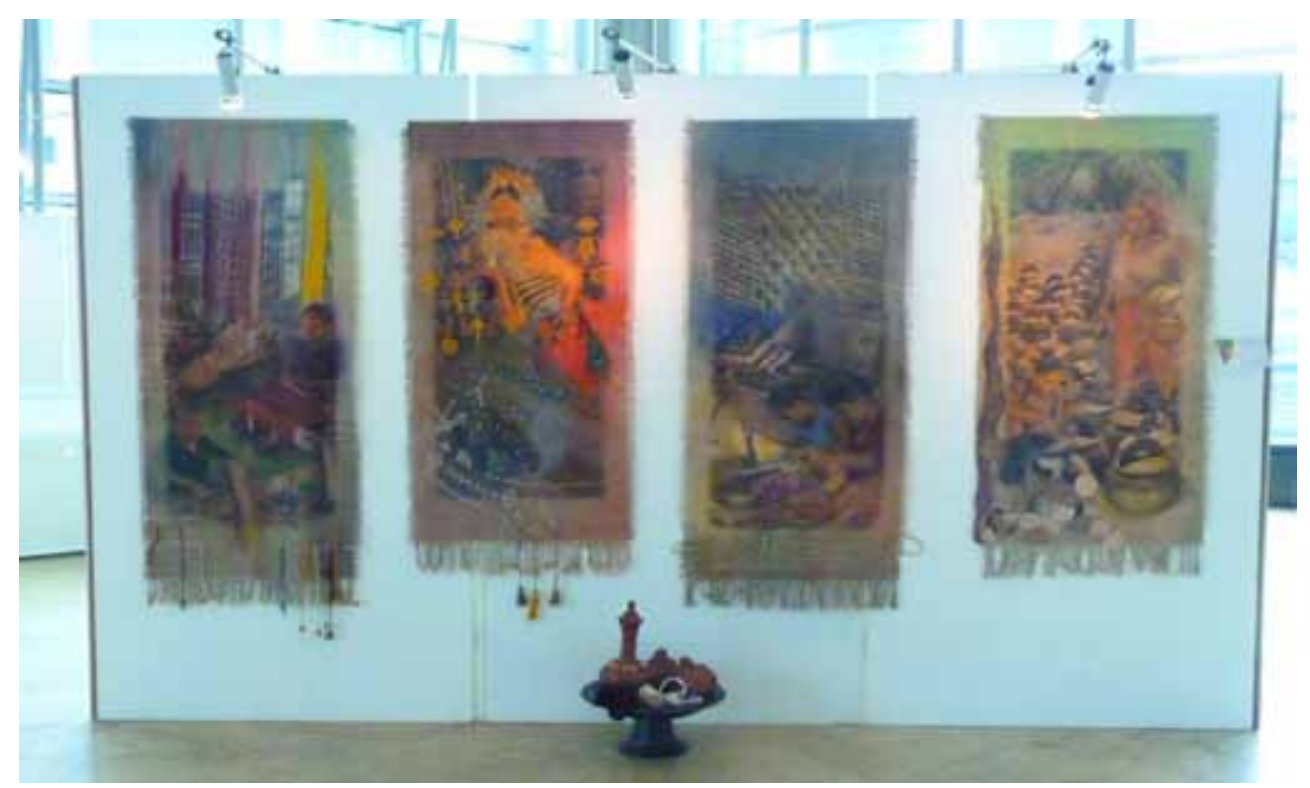

Figure 3. The two-dimensional work (Source: Lucky Wijayanti, 2015)

\section{REFERENCES}

Anthonie, Cornelis van Peursen. (1970). Strategie van de Cultuur, Amsterdam: Elsevier. (Disadur ke Bahasa Indonesia oleh Dick Hartoko (1988) dengan judul Strategi Kebudayaan, Yogyakarta: Kanisius.

Csikszentmihalyi, Mihaly. (1996).Creativity, Flow and the Psydhology of Discovery and Invention, New York: Harper Perennial.

Gray, Carole and Malins Julian. (2004).Visualizing Research, A Guide to the Research Process in Art and Design, England: Ashgate.

Jaszi, Peter et.al. (2009). Laporan Penelitian Kebudayaan Tradisional, Suatu Langkah Maju untuk Perlindungan di Indonesia, Jakarta: Lembaga Studi Pers dan Pembangunan (LSPP).

Jessup, Hellen Ibbitson. (1990).Court Arts of Indonesia, New York: The Asia Society Galleries.

Ramachandran V.S. ( 2012).The Tell - Tale Brain, London: Windmill Boks. 
Murata, Sachiko. (1992).The Tao of Islam, A Sourcebook on Gender Relationship inIslam Thought, New York: State University of New York Press, (Disadur ke Bahasa Indonesia oleh Rahmani Astuti (1996) dengan judul The Taoof Islam, Kitab Rujukan tentang Relasi Gender dalam Kosmologi danTeologi Islam, Bandung: Mizan.

Raap, Olivier Johannes. (2013). Pekerdja di Djawa Tempo Doeloe, Yogyakarta: Galang Pustaka.

Ratna, Nyoman Kutha SU. (2010). Metodologi Penelitian, Kajian Budaya dan Ilmu Sosial Humaniora Pada Umumnya, Yogyakarta: Pustaka Pelajar.

Walbi, Sylvia. (1990).Theorizing Patriarchy, United Kingdom: Oxford, (Disadur ke Bahasa Indonesia oleh Mustika K. Prasela (2014) dengan judul Teorisasi Patriaki, Yogyakarta: Jalasutra. 